\title{
KONTRIBUSI WADUK PEUDADA TERHADAP KEBUTUHAN AIR KABUPATEN BIREUEN
}

\author{
Wesli \\ Jurusan Teknik Sipil Universitas Malikussaleh \\ email:wesli@unimal.ac.id
}

\begin{abstract}
Abstrak
Kebutuhan air di Kabupaten Bireuen semakin hari semakin meningkat, kebutuhan tersebut digunakan untuk rumah tangga, peternakan dan kebutuhan air persawahan. Salah satu sumber untuk kebutuhan tersebut adalah waduk Peudada yang terletak di kecamatan Peudada Kabupaten Bireuen. Rumusan masalah adalah seberapa besar kontribusi waduk Peudada dalam memenuhi kebutuhan air di kabupaten Bireuen. Sumber air Waduk Peudada adalah curah hujan dan debit andalan Krueng Peudada. Penelitian ini bertujuan untuk mengetahui besarnya konstribusi Waduk Peudada dalam memenuhi kebutuhan air di kabupaten Bireuen. Metode penelitian dilakukan dengan analisis hidrologi dan analisis debit andalan sungai Krueng Peudada. Hasil penelitian menunjukkan bahwa ketersediaan air pada Waduk Peudada berdasarkan analisis hidrologi dan debit andalan sungai untuk kondidi eksisting sebesar $0,97 \mathrm{~m}^{3} / \mathrm{det}$, pada periode ulang 5 tahunan sebesar 11,242 $\mathrm{m}^{3} / \mathrm{det}$, pada periode ulang 10 tahunan sebesar $15,402 \mathrm{~m}^{3} / \mathrm{det}$, pada periode ulang 25 tahunan sebesar $20,662 \mathrm{~m}^{3} / \mathrm{det}$ dan pada periode ulang 50 tahunan sebesar $11,242 \mathrm{~m}^{3} /$ det. Kebutuhan air berdasarkan kebutuhan rumah tangga, kebutuhan peternakan dan kebutuhan air persawahan untuk kondidi eksisting sebesar $24,557 \mathrm{~m}^{3} / \mathrm{det}$, pada periode ulang 5 tahunan sebesar $24,562 \mathrm{~m}^{3} / \mathrm{det}$, pada periode ulang 10 tahunan sebesar $24,568 \mathrm{~m}^{3} / \mathrm{det}$, pada periode ulang 25 tahunan sebesar $24,600 \mathrm{~m}^{3} / \mathrm{det}$ dan pada periode ulang 50 tahunan sebesar $24,800 \mathrm{~m}^{3} /$ det. Berdasarkan hal tersebut maka dapat disimpulkan bahwa konstribusi Waduk Peudada dalam memenuhi kebutuhan air di Kabupaten Bireuen Pada periode ulang 25 tahunan kontribusi sebesar 83,99\% dan pada periode ulang 50 tahunan dapat berkondtribusi $99,02 \%$. Gambaran di atas menunjukkan bahwa untuk perencanaan infrastruktur ketersediaan air jika ingin memanfaatkan Waduk Peudada sebagai sumber penyediaan air harus pada periode ulang 25 tahunan atau 50 tahunan dan secara signifikan akan membutuhkan anggaran yang besar.
\end{abstract}

Kata kunci: Kebutuhan air, ketersediaan air, Kontribusi Waduk

\section{Pendahuluan}

Kabupaten Bireuen merupakan kabupaten otonom sejak tahun 2000 sebagai hasil pemekaran dari Kabupaten Aceh Utara. Kabupaten Bireuen juga terkenal dengan julukan kota juang secara geografis terletak pada $4^{\circ} 54^{\prime \prime}-5^{\circ} 21^{\prime}$ LU dan $96^{\circ} 20^{\prime \prime}-97^{\circ} 21^{\prime \prime} \mathrm{BT}$, dengan luas wilayah $1.901,121 \mathrm{Km}^{2}$ atau 190,121 Ha dengan batas-batas wilayah: Sebelah Utara dengan Selat Malaka, Sebelah Selatan dengan Kabupaten Bener Meriah dan Pidie, Sebelah Barat dengan Kabupaten Pidie dan Sebelah Timur dengan Aceh Utara. Jumlah kecamatan sebanyak 17 kecamatan yaitu: kecamatan Gandapura, kecamatan Jangka, kecamatan Jeunieb, kecamatan Jeumpa, kecamatan Juli, kecamatan kota juang, kecamatan Kuala, kecamatan Kuta Blang, kecamatan Makmur, kecamatan Pandrah, kecamatan Peudada, kecamatan Peusangan, kecamatan Peusangan Selatan, kecamatan Peusangan 
Siblah Krueng, kecamatan Plimbang, kecamatan Samalanga dan kecamatan Simpang Mamplam. Kabupaten Bireuen mempunyai penduduk 379.000 jiwa dengan mata pencaharian sebagian besar masyarakat adalah di bidang pertanian dan perikanan. Kebutuhan air di Kabupaten Bireuen semakin hari semakin meningkat, kebutuhan tersebut digunakan untuk rumah tangga, peternakan dan kebutuhan air persawahan. Salah satu sumber untuk kebutuhan tersebut adalah waduk Peudada yang terletak di kecamatan Peudada Kabupaten Bireuen.

Rumusan masalah adalah seberapa besar kontribusi waduk Peudada dalam memenuhi kebutuhan air di kabupaten Bireuen. Sumber air Waduk Peudada adalah curah hujan dan debit andalan Krueng Peudada. Penelitian ini bertujuan untuk mengetahui besarnya konstribusi Waduk Peudada dalam memenuhi kebutuhan air di kabupaten Bireuen.

\section{Tinjauan Kepustakaan}

\subsection{Analisa Hidrologi}

Analisa hidrologi bertujuan untuk menentukan debit maksimum pada suatu sungai. Analisa hidrologi yang dilakukan meliputi perhitungan curah hujan rencana dan debit banjir rencana. Pada debit banjir rencana dilakukan uji kecocokan distribusi Smirnov-Kolmogorov.

\subsubsection{Curah hujan rencana}

Menurut Wesli (2008), hujan rencana yang dimaksud adalah hujan harian maksimum yang akan digunakan untuk menghitung intensitas hujan, kemudian intensitas hujan ini digunakan untuk mengestimasi debit rencana. Hujan rencana dapat dihitung secara statistik berdasarkan data curah hujan terdahulu dengan menggunakan rumus sebagai berikut:

$$
\begin{aligned}
& \mathrm{Rr}=\bar{R}+\mathrm{k} \\
& \bar{R}=\frac{\sum_{i=1}^{n} R i}{n}
\end{aligned}
$$

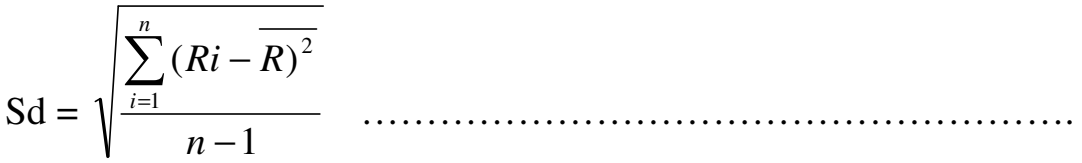

di mana :

$\mathrm{Rr}=$ Hujan rencana periode ulang $\mathrm{T}$ tahun $(\mathrm{mm})$;

$\bar{R}$ = Hujan harian tahunan maksimum rata-rata $(\mathrm{mm})$;

$\mathrm{K}=$ Faktor frekwensi untuk periode ulang $\mathrm{T}$ tahun sesuai dengan tipe sebaran data hujan;

$\mathrm{Sd}=$ Standar deviasi;

$\mathrm{Ri}=$ Hujan harian maksimum tahun ke-i;

$\mathrm{n}=$ Jumlah data atau tahun. 
Menurut Chow (1997), untuk menghitung besarnya curah hujan rencana berdasarkan curah hujan yang ada dapat dilakukan dengan menggunakan Metode Gumbel Tipe I dan Metode Haspers.

Metode Gumbel merupakan suatu cara yang paling sering digunakan dalam perhitungan curah hujan rencana yaitu dengan menggunakan persamaan analisis frekuensi yang telah disederhanakan yaitu sebagi berikut:

$$
\mathrm{Xt}=\mathrm{Xa}+\mathrm{k} \cdot \mathrm{Sx}
$$

di mana:

$\mathrm{Xt}=$ Besaran yang diharapkan terjadi dalam $\mathrm{T}$ tahun $(\mathrm{mm})$

$\mathrm{T}=$ Periode ulang (tahun)

$\mathrm{Xa}=$ Harga pengamatan rata-rata aritmatik $(\mathrm{mm})$

$\mathrm{k}=$ Faktor frekwensi

$\mathrm{Sx}=$ Simpangan standar (standard deviation)

Harga faktor frekuensi $(\mathrm{k})$ tergantung dari banyaknya data yang dianalisa, dan dari periode ulang yang dikehendaki sehingga dapat dirumuskan sebagai berikut :

$$
\begin{aligned}
& \mathrm{k}=\frac{Y t-Y n}{S n} \\
& \mathrm{Yt}=-\left(0,834+2,303 \log \log \frac{T}{T-1}\right) \\
& \mathrm{Xt}=X a+\frac{Y t-Y n}{S n} \cdot S x
\end{aligned}
$$

di mana:

$$
\begin{array}{ll}
\mathrm{Yt} & =\text { Reduced variated } \\
\mathrm{Yn} & =\text { Reduced mean } \\
\mathrm{Sn} & =\text { Reduced standard deviation }
\end{array}
$$

Untuk standar deviasi dapat digunakan rumus sebagai berikut :

$$
S=\sqrt{\frac{\sum_{i=1}^{n}(X i-X a)^{2}}{n-1}}
$$

\subsubsection{Periode ulang (return period)}

Menurut Chay Asdak (1995), periode ulang adalah periode waktu rata-rata yang diharapkan terjadi antara dua kejadian yang berurutan. Periode ulang (Tr) biasanya diprakirakan dari data curah hujan serial tahunan dengan bentuk persamaan:

$$
\operatorname{Tr}=\frac{n+1}{m}
$$

di mana :

$\mathrm{Tr}=$ Periode ulang (tahun)

$\mathrm{n}=$ Periode data debit yang tercatat

$\mathrm{m}=$ Jumlah kejadian, apabila disusun mulai yang terbesar sampai yang terkecil. 


\subsection{Debit Andalan (Q)}

Menurut Soemarto (1993), debit andalan yaitu jumlah air yang ada yang diperoleh dari data curah hujan, koefisien aliran, intensitas hujan dan koefisien tampungan. Untuk menghitung debit andalan dapat dihitung dengan menggunakan rumus rasional. Rumus ini banyak digunakan untuk sungai-sungai biasa dengan daerah pengaliran yang luas dan juga untuk perencanaan drainase daerah pengaliran yang relatif sempit. Rumus yang sering digunakan adalah sebagai berikut :

$$
Q=0,278 . C \cdot C S \cdot I . A
$$

di mana:

$$
\begin{array}{ll}
Q & =\text { Debit }\left(\mathrm{m}^{3} / \mathrm{det}\right) \\
C & =\text { Koefisien aliran } \\
C S & =\text { Koefisien tampungan } \\
I & =\text { Intensitas hujan selama waktu konsentrasi }(\mathrm{mm} / \mathrm{jam}) \\
A & =\text { Luas daerah aliran }\left(\mathrm{km}^{2}\right)
\end{array}
$$

\subsection{Intensitas hujan (I)}

Menurut Wesli (2008), intensitas hujan adalah jumlah hujan yang dinyatakan dalam tinggi hujan atau volume hujan tiap satuan waktu atau intensitas hujan adalah ketinggian hujan yang terjadi pada suatu kurun waktu air hujan terkonsentrasi. Di Indonesia alat pengukur hujan yang paling banyak digunakan adalah alat pencatat hujan biasa yang mengukur hujan 24 jam atau disebut hujan harian. Apabila yang tersedia hanya data hujan harian maka intensitas hujan dapat diestimasi dengan menggunakan rumus Mononobe sebagai berikut:

$$
I=\frac{\mathrm{R}_{24}}{24}\left(\frac{24}{\mathrm{t}}\right)^{2 / 3}
$$

di mana :

$$
\begin{array}{ll}
\mathrm{I} & =\text { Intensitas curah hujan (mm/jam) } \\
\mathrm{R}_{24} & =\text { Curah hujan maksimum dalam } 24 \text { jam (mm) } \\
\mathrm{t} & =\text { Durasi (lamanya) curah hujan (menit) atau (jam) }
\end{array}
$$

\subsection{Kebutuhan Air}

Menurut Razuardi (2005), kebutuhan air merupakan akumulasi dari kebutuhan air seperti kebutuhan air untuk rumah tangga, peternakan dan persawahan. Untuk menentukan kebutuhan air dapat digunakan persamaan sebagai berikut:

$$
Q_{K A}=Q_{R T}+Q_{T}+Q_{S}
$$

di mana :

$\mathrm{Q}_{\mathrm{KA}}=$ Kebutuhan air

$\mathrm{Q}_{\mathrm{RT}}=$ Kebutuhan air rumah tangga

$\mathrm{Q}_{\mathrm{T}} \quad=$ Kebutuhan air ternak

$\mathrm{Q}_{\mathrm{S}} \quad=$ Kebutuhan air sawah

\section{Metode Penelitian}

Kontribusi Waduk Peudada Terhadap Kebutuhan Air Kabupaten Bireuen - Wesli 
Metode penelitian dilakukan dengan dengan analisis hidrologi dan analisis debit andalan sungai Krueng Peudada. Analisis hidrologi berdasarkan curah hujan yang menghasilkan debit kawasan. Analisis debit andalan sungai dilakukan dengan menghitung jumlah debit yang paling minimal untuk mengisi tampungan waduk peudada. Kedua debit tersebut akan menjadi debitketersediaan. Kemudian dihitung debit kebutuhan melalui akumulasi dari kebutuhan rumah tangga, kebutuhan peternakan dan kebutuhan air di persawahan, kemudian diperbandingkan untuk mendapatkan besaran kontribusi.

\section{Hasil dan Pembahasan}

\subsection{Analisa Ketersediaan Air}

Dalam estimasi ketersediaan air dibutuhkan suatu data curah hujan. Data yang digunakan data curah hujan tahun 1998 - 2007. Data yang terbilang pendek ini digunakan untuk menggambarkan besaran debit yang terjadi, juga digunakan untuk menghitung debit andalan dengan peluang $80 \%$ dan debit andalan dengan periode ulang yang telah ditentukan. Perhitungan ketersediaan air dilakukan untuk mengetahui debit air normal yang akan mengisi waduk dan untuk mengetahui seberapa besar ketersediaan air. Debit andalan sangat dipengaruhi oleh beberapa faktor yaitu koefisien aliran, koefisien tampungan, intensitas hujan dan luas daerah alirannya. Hasil curah hujan pada probabilitas $80 \%$ adalah sebesar 13,182 $\mathrm{mm}$ dan debit andalan untuk $\mathrm{Q}_{80}$ sebesar $0,971 \mathrm{~m}^{3} /$ det.

\subsection{Analisa Kebutuhan Air}

Analisa kebutuhan air terdiri dari kebutuhan air rumah tangga, peternakan dan persawahan bahwa dengan bertambahnya jumlah pengguna air sungai maka kebutuhan air juga semakin meningkat akan tetapi berdasarkan hasil perhitungan volume air yang tersedia tidak mencukupi untuk kebutuhan air dalam masa periode ulang $5,10,25$ dan 50 tahun.

\subsubsection{Kebutuhan air untuk rumah tangga}

Jumlah penduduk yang menggunakan air di sepanjang aliran sungai adalah 21.705 jiwa di mana per orang mengkonsumsi air sebesar 90 liter/hari atau 1,04 x $10^{-6} \mathrm{~m}^{3} /$ det. Sesuai dengan bertambahnya jumlah penduduk untuk 5 tahun sebesar 24.677 jiwa, maka kebutuhan airnya juga bertambah 2.220 .930 liter/hari atau $0,026 \mathrm{~m}^{3} /$ det. Sedangkan untuk 10 tahun jumlah penduduk sebesar 28.056 jiwa dan jumlah kebutuhan airnya sebesar 2.525 .040 liter/hari atau $0,029 \mathrm{~m}^{3} / \mathrm{det}$, sementara untuk 25 tahun jumlah penduduknya sebesar 41.233 jiwa dengan jumlah kebutuhan air sebanyak 3.710.970 liter/hari atau $0,043 \mathrm{~m}^{3} /$ det dan untuk periode ulang 50 tahun jumlah penduduk sebesar 78.330 jiwa dan kebutuhan air 7.049.700 liter/hari atau $0,082 \mathrm{~m}^{3} /$ det.

\subsubsection{Kebutuhan air untuk peternakan}

Selain untuk rumah tangga, air sungai tersebut juga digunakan untuk kebutuhan peternakan di mana ternak yang menggunakan air tersebut meliputi lembu, kerbau, domba, kambing, ayam dan itik. Jumlah sapi/lembu 5.673 ekor dengan kebutuhan 15 liter/ekor/hari sehingga kebutuhan air sebesar 85.095 liter/hari atau $9,85 \times 10^{-4} \mathrm{~m}^{3} /$ det. Jumlah kerbau 694 ekor dengan kebutuhan 20 liter/ekor/hari sehingga kebutuhan air sebesar 13.880 liter/hari atau 1,61 x $10^{-4}$ 
$\mathrm{m}^{3}$ /det. Jumlah kambing 3.920 ekor dengan kebutuhan 10 liter/ekor/hari sehingga kebutuhan air 39.200 liter/hari atau $4,5 \times 10^{-4} \mathrm{~m}^{3} /$ det. Jumlah domba 1.135 ekor dengan kebutuhan 10 liter/ekor/hari sehingga kebutuhan air 11.350 liter/hari atau $1,3 \times 10^{-4} \mathrm{~m}^{3} /$ det. Jumlah ayam buras 28.133 ekor dengan kebutuhan 5 liter/ekor/hari sehingga kebutuhan air 140.665 liter/hari atau $1,6 \times 10^{-3} \mathrm{~m}^{3} /$ det. Jumlah ayam pedaging 1.440 ekor dengan kebutuhan 5 liter/ekor/hari sehingga kebutuhan air 7.200 liter/hari atau $8,3 \times 10^{-5} \mathrm{~m}^{3} /$ det. Jumlah itik 9.902 ekor dengan kebutuhan 5 liter/ekor/hari sehingga kebutuhan air 49.510 liter/hari atau $5,7 \times 10^{-4} \mathrm{~m}^{3} /$ det.

\subsubsection{Kebutuhan air untuk persawahan}

Kebutuhan air di sawah dapat dibedakan atas kebutuhan kotor air di sawah (GFR) dan kebutuhan bersih air di sawah (NFR). Pada perhitungan GFR, besaran curah hujan efektif tidak dimasukkan ke dalam perhitungan. Sementara untuk perhitungan NFR besaran curah hujan efektif turut dimasukkan ke dalam perhitungan. Dari hasil perhitungan, besarnya kebutuhan air di sawah atau besarnya debit intake untuk persawahan seluas 1.071 ha adalah sebesar 24,530 $\mathrm{m}^{3} /$ det.

\subsection{Komparasi Kebutuhan Air dan Ketersediaan Air}

Dari hasil kebutuhan air dan ketersediaan air maka dapat dilakukan komparasi untuk melihat selisih dari keduanya seperti diperlihatkan pada Tabel 1.

Tabel 1 Komparasi Kontribusi kebutuhan dan ketersediaan air

\begin{tabular}{|l|c|c|c|c|}
\hline \multicolumn{1}{|c|}{ Kondisi } & $\begin{array}{c}\text { Ketersediaan } \\
\text { air }\left(\mathrm{m}^{3} / \mathrm{det}\right)\end{array}$ & $\begin{array}{c}\text { Kebutuhan } \\
\text { air }\left(\mathrm{m}^{3} / \mathrm{det}\right)\end{array}$ & $\begin{array}{c}\text { Selisih } \\
\left(\mathrm{m}^{3} / \mathrm{det}\right)\end{array}$ & $\begin{array}{c}\% \\
\text { Kontribusi }\end{array}$ \\
\hline Eksisting & 0.971 & 24.557 & -23.586 & 3.95 \\
\hline Periode ulang 5 tahunan & 11.242 & 24.562 & -13.320 & 45.77 \\
\hline Periode ulang 10 tahunan & 15.402 & 24.568 & -9.166 & 62.69 \\
\hline Periode ulang 25 tahunan & 20.662 & 24.600 & -3.938 & 83.99 \\
\hline Periode ulang 50 tahunan & 24.557 & 24.800 & -0.243 & 99.02 \\
\hline
\end{tabular}

Dari Tabel 1 meggambarkan bahwa komparasi kebutuhan air dengan ketersediaan air hanya dapat tercukupi pada debit periode ulang 50 tahunan. Kontribusi waduk terhadap kebutuhan air di kabupaten Bireuen pada kondisi eksisting sebesar 3,95\%. Sementara itu pada periode ulang 5 tahunan dapat berkontribusi sebesar 45,77\%. Untuk periode ulang 10 tahunan kontribusi sebesar $62,69 \%$. Pada periode ulang 25 tahunan kontribusi sebesar 83,99\% dan pada periode ulang 50 tahunan dapat berkondtribusi 99,02\%. Gambaran di atas menunjukkan bahwa untuk perencanaan infrastruktur ketersediaan air jika ingin memanfaatkan Waduk Peudada sebagai sumber penyediaan air harus pada periode ulang 25 tahunan atau 50 tahunan dan secara signifikan akan membutuhkan anggaran yang besar. 


\section{Kesimpulan dan Saran}

\subsection{Kesimpulan} berikut:

Berdasarkan hasil kajian dapat diambil beberapa kesimpulan sebagai

1. Ketersediaan air berdasarkan analisis hidrologi dan debit andalan sungai untuk kondidi eksisting sebesar $0,97 \mathrm{~m}^{3} /$ det, pada periode ulang 5 tahunan sebesar $11,242 \mathrm{~m}^{3} / \mathrm{det}$, pada periode ulang 10 tahunan sebesar $15,402 \mathrm{~m}^{3} / \mathrm{det}$, pada periode ulang 25 tahunan sebesar $20,662 \mathrm{~m}^{3} /$ det dan pada periode ulang 50 tahunan sebesar $11,242 \mathrm{~m}^{3} /$ det.

2. Kebutuhan air berdasarkan kebutuhan rumah tangga, kebutuhan peternakan dan kebutuhan air persawahan untuk kondidi eksisting sebesar $24,557 \mathrm{~m}^{3} / \mathrm{det}$, pada periode ulang 5 tahunan sebesar $24,562 \mathrm{~m}^{3} / \mathrm{det}$, pada periode ulang 10 tahunan sebesar $24,568 \mathrm{~m}^{3} / \mathrm{det}$, pada periode ulang 25 tahunan sebesar 24,600 $\mathrm{m}^{3} /$ det dan pada periode ulang 50 tahunan sebesar $24,800 \mathrm{~m}^{3} /$ det.

3. Kontribusi waduk terhadap kebutuhan air di kabupaten Bireuen pada kondisi eksisting sebesar 3,95\%. Sementara itu pada periode ulang 5 tahunan dapat berkontribusi sebesar $45,77 \%$. Untuk periode ulang 10 tahunan kontribusi sebesar 62,69\%. Pada periode ulang 25 tahunan kontribusi sebesar 83,99\% dan pada periode ulang 50 tahunan dapat berkondtribusi 99,02\%.

4. Gambaran di atas menunjukkan bahwa untuk perencanaan infrastruktur ketersediaan air jika ingin memanfaatkan Waduk Peudada sebagai sumber penyediaan air harus pada periode ulang 25 tahunan atau 50 tahunan dan secara signifikan akan membutuhkan anggaran yang besar.

\subsection{Saran}

Saran sebagai bentuk rekomendasi dari penelitian ini adalah untuk perencanaan infrastruktur ketersediaan air jika ingin memanfaatkan Waduk Peudada sebagai sumber penyediaan air harus pada periode ulang 25 tahunan atau 50 tahunan dan secara signifikan akan membutuhkan anggaran yang besar.

\section{Daftar Kepustakaan}

Anonim, 2006, Bireuen Dalam Angka, BPS dan Bappeda, Bireuen.

Asdak Chay, 1995, Hidrologi dan Pengelolaan Daerah Aliran Sungai, Gadjah Mada University Press, Yogyakarta.

Chow, V.T., 1997, Hidrolika Saluran Terbuka, Alih Bahasa Nensi Rosalina, Erlangga, Jakarta.

Direktorat Jenderal Pengairan, 1986, Standar Perencanaan Irigasi (KP-01), Badan Penerbit Pekerjaan Umum, Jakarta.

Razuardi, Ir., MT., 2005, Pengaruh Optimasi Infiltrasi Tata Guna Lahan di Banda Aceh Tahun 2010, Jurusan Teknik Sipil Universitas Syiah Kuala, Banda Aceh.

Soemarto, C.D., 1993, Hidrologi Teknik, Erlangga, Jakarta.

Wesli, Ir., 2008, Drainase Perkotaan, Graha Ilmu, Yogyakarta. 